\title{
Promoting hauora during COVID-19: Time to listen to the narratives of Māori nurses and leaders
}

Kiri Hunter ${ }^{1,2}, \mathrm{MN}, \mathrm{RN}, \mathrm{PhD}$ Candidate, School of Clinical Sciences; Ngāti Kahungunu, Rangitāne, Ngāti Maniapoto

Zoe Tipa ${ }^{1}, \mathrm{PhD}$, RN, Senior Lecturer, School of Clinical Sciences; Kāi Tahu, Ngāti Kahungunu

${ }^{1}$ Auckland University of Technology, Auckland, Aotearoa New Zealand 2Corresponding Author: Kiri.Hunter@nmit.ac.nz

\author{
Citation \\ Hunter, K., \& Tipa, Z. (2021). Promoting \\ hauora during COVID-19: Time to listen to the \\ narratives of Māori nurses and leaders. \\ [Editorial]. Nursing Praxis in Aotearoa New \\ Zealand, 37(3), 6-7. \\ https://doi.org.10.36951/27034542.2021.045
}

For Māori terms, please see the Nursing Praxis Te Reo Glossary

This special issue of Nursing Praxis in Aotearoa New Zealand reflects how rapidly COVID-19 has changed the landscape of global health and highlights the impact of health and social inequities across Indigenous communities (see, in this issue, Clark et al., 2021, COVID-19 among Indigenous communities). In this editorial we honour the otherwise invisible and underrecognised work of Māori nurses as they fortify and weld together their respective communities in the face of very real threats to hauora Māori. We draw upon a whakataukī or 'proverb' that speaks to Māori perspectives of time and protective guidance:

\section{Kia whakatomuri te haere whakamua}

\section{I walk backwards into the future with my eyes fixed on my past}

This whakatauki encapsulates how the past is central to and shapes both present and future identity (Rameka, 2016). It reminds us that the strength of carrying one's past into the future is that our ancestors are ever present, both physically and spiritually (Walker, 1996). There are fundamental beliefs, values, and attributes inherited from our tūpuna (ancestors) that guide Māori nurses in their practices today. Many kaupapa Māori principles provide blueprints of how to respond during events like COVID-19.

COVID-19 presents not only a very real threat to hauora Māori but also to whakapapa (the line of descent from one's ancestors). Whakapapa literally means "the process of layering one thing upon another" (Ngata, 2011, p.6). The natural and spiritual histories of Māori as a collective and as individuals are organised by whakapapa. We reflect on the 191819 influenza pandemic, which had a devastating impact on the Māori population (Ministry of Health, 2020), and are also drawn to remember our tūpuna Te Puea Hērangi, an influential Māori leader who took the most active leadership role in Waikato in her generation. Te Puea's legacy was to inspire unity; she was a woman of great mana (spiritual authority) and vision who persevered with courage and hard work to help restore the honour and strength of her Tainui people (King, 1977; Parsonson, n.d.).

Underpinning Te Puea's leadership style were the values of manaaki tangata - to care for others; and mahia te mahi, hei painga mō te iwi - doing what is necessary for the wellbeing of the people. Kaitiakitanga is often translated as referring to guardianship or protection, however Kawheru (2000) argues that kaitiakitanga needs to be understood in terms of how mana is maintained, mauri (lifeforce) is protected, tapu (sacredness) is respected, and manaaki (hospitality) is upheld. Te Puea witnessed Māori communities not being able to access the same health care as Pākehā, with "...no outside doctors visiting with assistance... a great deal of contradictory advice... and few supplies recommended for use preventatively and to alleviate symptoms after onset" (King, 1977, p. 100). Māori nurses today are faced with needing to identify ways to protect the mana of whānau during COVID-19 within a health system that has long disregarded it. Māori have a lengthy history of providing health services for whānau, hapū, and iwi against structures 
that often do not reflect Māori realities. Working within the confines of inequitable access to healthcare is not a new phenomenon.

The government can learn from the past in terms of what works for Māori today and Māori nurses need to be supported by a health system that is fit for Māori. One hundred years ago Te Puea envisaged a community built on the social determinants of health and attempted to build a for-Māori-by-Māori health system, but plans were blocked by local health authorities (Kerr, 2021). Today's nurses draw from mātauranga Māori (Māori knowledge), tikanga (both traditional customs and practices, and innovations) and whakawhanaungatanga (the process of building relationships) to connect with whānau and include them in decision-making regarding the protection of their whakapapa (lineage). They navigate ongoing challenges to present culturally specific solutions within a hesitant system where the locus of control is disproportionately held by non-Māori. By surfacing and privileging the dominant narratives of Māori nursing leaders, (see, in this issue, Davis et al., 2021, Steadfast is the rock), what is truly important to whānau, hapū, and iwi is made crystal clear. As collaborative and holistic health system designers, Māori nurse leaders, nurses and tauiwi allies represent the true Māori health authority.

\section{References}

Clark, T. C., Best, O., Bourque Bearskin, L., Wilson, D., Power, T., Phillips-Beck, T., Graham, H., Nelson, K., Wilkie, M., Lowe, J., Wiapo, C., \& Brockie, T. (2021). COVID-19 among Indigenous communities: Case studies on Indigenous nursing responses in Australia, Canada, New Zealand, and the United States. Nursing Praxis in Aotearoa New Zealand, 37(3), 71-83. https://doi.org.10.36951/27034542.2021.037
Davis, J., Wiapo, C., Rehana-Tait, H., Clark, T., \& Adams, S. (2021). Steadfast is the rock: Primary health care Māori nurse leaders discuss tensions, resistance, and their contributions to prioritise communities and whānau during COVID-19. Nursing Praxis in Aotearoa New Zealand, 37(3), 84-93. https://doi.org.10.36951/27034542.2021.038

Kawharu, M. (2000). Kaitiakitanga: A Māori anthropological perspective of the Māori socioenvironmental ethic of resource management. The Journal of the Polynesian Society, 109(4), 349-370.

Kerr, F. (2021). Ngāruawāhia locals want the kind of healthcare first envisioned by Princess Te Puea Hērangi 100 years ago.

https://www.stuff.co.nz/national/health/300301648 /ngruawhia-locals-want-the-kind-of-healthcare-firstenvisioned-by-princess-te-puea-hrangi-100-years-ago

King, M. (1977). Te Puea, a biography. Hodder and Stoughton.

Ministry of Health. (2020). Initial COVID-19 Māori response action plan. Ministry of Health. https://www.health.govt.nz/publication/initial-covid19-maori-response-action-plan

Ngata, A. T. (2011). The Porourangi Māori Cultural School, Rauru-nui-a-Toi Course, Lectures 1-7. Māori Purposes Fund Board/Te Rūnanga o Ngāti Porou.

Parsonson, A. (n.d.). 'Hērangi, Te Kirihaehae Te Puea'. Dictionary of New Zealand Biography, Te Ara. https://teara.govt.nz/en/biographies/3h17/herangite-kirihaehae-te-puea

Rameka, L. (2016). Kia whakatōmuri te haere whakamua: 'I walk backwards into the future with my eyes fixed on my past'. Contemporary Issues in Early Childhood, 17, 387-398. https://doi.org/10.1177/1463949116677923

Walker, R. (1996). Ngā pepa a Ranginui: The Walker papers. Penguin Books. 